INTERNATIONAL JOURNAL OF RESEARCHES IN BIOSCIENCES, AGRICULTURE AND TECHNOLOGY (c) VISHWASHANTI MULTIPURPOSE SOCIETY (Global Peace Multipurpose Society) R. No. MH-659/13(N) www.vmsindia.org

\title{
Hydro-chemical Monitoring of Ground Water in the Vicinity of Umrer Mining Area, Nagpur
}

Bharati S. Tapase

Dept. of Environmental Science, Sevadal Mahila Mahavidyalaya, Nagpur. (M.S.) Email: tapasebharati@rediffmail.com

\section{Abstract:}

Ground water samples (Bore wells) used as drinking water in mining area near Umrer, were analysed for $\mathrm{pH}$, Tempe rature, Total solids, Chloride, Sulphate, Dissolved oxygen and Bio-chemical oxygen de mand for a pe riod of one year (2016-17). The quality of samples were as sessed with drinking water standards by WHO (1984) and BIS (1998), as the ground water is used for drinking purpose, the samples of all the stations were found to be beyond the drinking water standards of WHO. The increased values obse rved in all the hydro-chemical parameters are attributed to the leaching from the soil. In this analysis it was noticed that all the parameters levels in the ground water increased, indicating the increase d pollution of ground water day by day making the most of the ground water non-palatable.

Key Words: Vicinity, Hydro-chemical parameter, Quality indices, MKD-II, Pollution.

\section{Introduction:}

India is a tropical country with a vast dive rsity of climate, topography and vege tation. Though blessed with fairly high annual rainfall, it is not uniformly distributed in the time and space resulting in the bulk of rain fall escaping as runoff, this results in incomplete utilization of available surface water. The scarcity of surface water especially in the lean season in the most parts of the country means that ground water plays a decisive role. Therefore efforts we re made to study the ground water pollution of mining area in order to assess its pollution status. The present paper attempts to evaluate the quality of ground water in residential areas and mining areas near Umrer.

Pollution of groundwater resources has become a major problem today. The land and mining industries have adversely affected the quality of air, wate $r$ and soil and also the ground water. Millions of peoples all over the world over are affected by water pollution marked by excess fluoride, arse nic, iron or the ingress if salt water. Pure water is essential for survival of human beings. Precious resources are degraded day by day due to human activities. Exploding population and increasing industrialization, urbanisation, agricultural and mining sources has become a major concern for the welfare of mankind. Groundwater offers security as a source of supplied of pure water during extended dry periods as compared to most surface water resources. The Hydro-chemical analysis was carried out to examine its suitability for d rinking, domestic and agricultural purpose.

Keeping the above facts in mind, it is proposed to study the detrimental effects of mining effluents on ground water quality of mining area, Umrer.

\section{Study Area:}

Ground water samples were collected from in and around the mining area of Umrer. Each water sample was taken every season (Monsoon, Winter and Summer) during June 2016 to May 2017. The samples were collected in prewashed (with detergent, dilute $\mathrm{HNO}_{3}$ and double distilled water, respectively). Clean polythene bottles without any air bubbles and tightly sealed after collection and labelled in the field. The temperatures of the samples were measured in the field on the spot at the time of sample colle ction. The samples we re immediately analysed in the laboratory to minimize hydrochemical changes.

\section{Sampling sites:}

Site A- Bore well water from TSM colony of MKD mining are a (1.5 Km from mines).

Site B- Canal water where the colony waste is discharged (flows in Aam river passing through the mining area $-0.5 \mathrm{Km}$ from $\mathrm{MKD}-\mathrm{I}$ mine)

Site C- Bore Well water of field area of MKD II mine.

Site D- Bore Well water from agricultural field near MKD-II ( $4 \mathrm{Km}$ from MKD-II mine).

\section{Research Methodology:}

The ground water samples are collected during the period June 2016 to May 2017. From three bore wells and one canal located in the study area. The quality analysis has been carried out for the parameters like $\mathrm{pH}$, temperature, total solids, sulphate, chlorides, dis solved oxygen and BOD. All the samples we re brought immediately to the laboratory for analysis of all the parameters by following standard methods prescribed as per IS:10500-1994 Codes, APHA (2005). These values were compared with Indian Standard Specification for drinking water as given by Ramteke and Moghe (1988). 
Result and Discussion:

Table-1: Season wise concentration of water quality parameters in ground water sample (June 2016 May 2017).

\begin{tabular}{|c|c|c|c|c|c|c|c|c|c|}
\hline \multirow[t]{2}{*}{ S.N. } & \multirow[t]{2}{*}{ Sites } & \multirow[t]{2}{*}{ Season } & \multicolumn{7}{|c|}{ Parameters } \\
\hline & & & pH & $\begin{array}{l}\text { Temp } \\
\text { oC }\end{array}$ & $\begin{array}{l}\text { Chloride } \\
\text { mg/lit }\end{array}$ & $\begin{array}{l}\text { TS } \\
\text { mg/lit }\end{array}$ & $\begin{array}{l}\text { Sulphate } \\
\text { mg/lit }\end{array}$ & $\begin{array}{l}\text { DO } \\
\text { mg/lit }\end{array}$ & $\begin{array}{l}\text { BOD } \\
\text { mg/lit }\end{array}$ \\
\hline \multirow[t]{3}{*}{$\mathbf{1}$} & \multirow[t]{3}{*}{ Site A } & Mon & 8.1 & 28 & 90 & 1050 & 1100 & 3.1 & 32.0 \\
\hline & & Wint & 8.3 & 26 & 85 & 950 & 800 & 3.0 & 30.1 \\
\hline & & Sum & 8.3 & 33 & 80 & 950 & 800 & 2.9 & 32.3 \\
\hline \multirow[t]{3}{*}{2} & \multirow[t]{3}{*}{ Site B } & Mon & 8.2 & 28 & 110 & 3050 & 1050 & 3.8 & 35.3 \\
\hline & & Wint & 8.2 & 26 & 105 & 3000 & 850 & 3.6 & 34.8 \\
\hline & & Sum & 8.3 & 32 & 95 & 3000 & 950 & 3.5 & 34.1 \\
\hline \multirow[t]{3}{*}{3} & \multirow[t]{3}{*}{ Site C } & Mon & 8.0 & 28 & 270 & 2000 & 1080 & 3.2 & 34.3 \\
\hline & & Wint & 8.0 & 25 & 240 & 1990 & 1020 & 3.0 & 33.0 \\
\hline & & Sum & 8.1 & 33 & 230 & 1995 & 1000 & 3.1 & 33.1 \\
\hline \multirow[t]{3}{*}{4} & \multirow[t]{3}{*}{ Site D } & Mon & 8.2 & 27 & 250 & 2050 & 1080 & 3.0 & 34.8 \\
\hline & & Wint & 8.3 & 26 & 255 & 1800 & 1000 & 3.0 & 33.2 \\
\hline & & Sum & 8.3 & 33 & 260 & 1800 & 1010 & 3.1 & 31.8 \\
\hline
\end{tabular}

Table-2: Bureau of Indian Standard Specification IS: $10500-1994$

\begin{tabular}{|l|l|l}
\hline S.N. & Parameter & IS:10500-1994 \\
\hline 1. & pH & $6.5-8.5$ \\
\hline 2. & Temp & - \\
\hline 3. & Chlorides & $250 \mathrm{mg} /$ lit \\
\hline 4. & TS & $500 \mathrm{mg} /$ lit \\
\hline 5. & Sulphate & $200 \mathrm{mg} /$ lit \\
\hline 6. & DO & $4.0-6.0 \mathrm{mg} /$ lit \\
\hline 7. & BOD & $30 \mathrm{mg} /$ lit \\
\hline
\end{tabular}

The values of diffe rent hydro-chemical parame te rs obtained after the analys is of ground water from four different stations presented in the Table -1 . These values were compared with Indian Standard Specification for drinking wate $r$ and given by Ramteke and Moghe (1988) Table2 . The values of diffe rent parame te rs obtained in the analysis of ground water polluted by coal mine lead to us the following results.

It was clear that the polluted ground water by coal mine was darkly coloured having objectionable smell. It also showed considerable high total solids, chlorides, sulphates, DO and BOD.

The result obtained in the present study on BOD of the mining wate $r$ is beyond the tolerance limit as suggested by Indian Standard Specification for drinking water.

Chloride behind the desirable limit causes corrosion and palatability of water. H. Vidyavathi (2009)

The sulphates more than the tolerance limit causes gastrointestinal irritation (Todd, 1980).

$\mathrm{pH}$ is considered as important hydrochemical parameter in water body since most of the aquatic organism are adapted to an average $\mathrm{pH}$. $\mathrm{pH}$ values varied from 8.0 to 8.3 are suitable for animals (Subbmma and Rama, 1992). Similar trends also have been obse rved by (Prapurna and Shashikant, 2002), Gangotri (2009).

Total solids value of ground water was noted to be ranges between 950 to $3050 \mathrm{mg} /$ lit. during the study period. The above result is supported by (Verma et. al. 1978).

Dissolved oxygen, A use ful parame te $r$ to assess the quality of water. Tempe rature will play an important role in determining DO in an aquatic system in ground wate $r$ it ranges from 2.9 to $3.8 \mathrm{mg} /$ lit. The high level of DO was observed in summer month. Similar high DO values have been reported by (Devidas Kamath et. al. 2006).

High BOD indicated highe r consumption of oxygen and a higher pollution in water (Mahida, 1981), Vasumathi Reddy (2009).

Majority of the people depend on the ground water for their requirement therefore it is very essential to protect these water resources from being contaminated by mining processes. Hence proper treatment and management can help to protect ground water from contamination.

\section{Conclusion:}

The fluctuations in the hydro-chemical parameters were observed from all sampling sites. In general, all the parameters are exceeds the range of standard values prescribed by health organizations. The obtained result indicates that the ground water quality of mining a reas is not suitable for drinking, domestic and other purpose. It can be used after proper treatment and management. 


\section{References:}

APHA (2005). Standard methods for the examination of wate $r$ and wastewater, American Public Health Association, Washington DC. U.S.A. $21^{\text {st }}$ edition.

BIS (1998): "Specification for drinking water," New Delhi.

WHO (1984): Guidelines for drinking water quality (Vol. 2): Health criteria and other supporting information. World Health Organization, Ge neva.

Ramteke, D. S. and Moghe, C. A. (1988): Manual of water and waste water analysis Hindustan Publishing Corporation, New Delhi: 265.

Todd, D.K. (1980): G round wate r hydrology, John Wiley, New York, USA.pp 426 - 447.

Subbamma, D. V. and Rama, D. V. (1992): Plankton of Temple Pond near Machaliptanaum. J. Aqua. Biol. Vol. VII: pp 17-21.

Prapurna, N. And Shashikant, K. (2002): Pollution level in Hussain Sagar Lake of
Hyde rabad. A case study. Poll. Res. 2 1(2); pp $187-$ 190.

Gangotri V. M. and Mudkhede L. M.* (2009), J. Aqua. Biol., Vol 24(1), 2009: pp 95-98.

Verma, S. R., D. K. Bahel, N. Pal and R. C. Dalela (1978): Studies on the sugar factories and their wastes in western Utter Pradesh. Ind. J. Env. Hlth., Vol. 20(3): pp 204-218.

Devidas Kamath, E. T. Puttaih and B. R. Kiran (2006): Status of Water Quality in Ayanur tank near Shimoga District, Karnataka, Nature environment and Pollution Technology., 5(2): pp 257-260.

Mahida, UN (1981): Water Pollution and dispose of waste water on land Tata, McGraw Hill Publishing Co., New Delhi.pp. 201-209.

Vasumathi Reddy , K., Laxmiprasd. K.*, Swami,

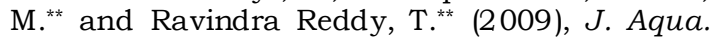
Biol., Vol 24(1), 2009: pp 77-80.

H. Vidyavathi, B. E. Basavarajappa and E. T. Puttaiah (2009), J. Aqua. Biol., Vol 24(1), 2009: pp 81-86. 